\title{
Forme ale demitizării în imaginarul poetic religios al lui Panait Cerna
}

\author{
Drd.CARP (TANASACIUC) Valentina-Luminiţa \\ Universitatea „Dunărea de Jos” din Galați
}

Abstract: The poetic imagery of Panait Cerna also has a component of faith as a concretized form of traditional spirituality. Through religious poetry, Cerna illustrates a direction of literature, backed by time publications that have shaped the traditional pattern of existence. His work is the expression of Romanian spirituality in axiological moments, when new cultural values were sought. The poet's religious poem is part of the poetry where the subject is humanity and not the individual. Although there were critics who said that the language used by Cerna did not have a great glow, through the vitality of sentiments, it remains the noblest contribution to overcoming Eminescu's patterns. The value of Panait Cerna's religious poetry is indisputable, especially when overtaking the individual and encompassing the universe, it reaches an original, original concept. Thus, his poetry rises above his age and has a special place in the Romanian lyrical ensemble.

Keywords: Panait Cerna, religious poetry, religious imaginary, icon

Literatura română contemporană înregistrează în ultima perioadă un proces de restructurare a setului de valori şi o mutație în cuprinsul canonului. Ideea „revizitării” operelor literare, în special a celor aparținând scriitorilor considerați de teoreticienii timpului autori canonici, contractează, în acest sens, o consistență semnificativă, mai ales, că intenția este de a se pune în evidență noi componente ale operelor și de a îmbogăți reperele culturale ale unei epoci demult încheiate.

Orice literatură nu poate face abstracție de esența ființei umane și anume, de ființa iubitoare de Dumnezeu și de semeni, esență ce reprezintă dimensiunea de homo religiosus. Raportat la existența umană, omul este o ființă religioasă aflată în permanentă căutare a divinității. S-a constatat că relația omului cu divinitatea nu este doar ascendentă (ființa care își dorește să îl întâlnească pe Dumnezeu), ci şi una descendentă (Dumnezeu descinde în universul omului, în ființa umană, El Însuşi devenind Om şi avându-l pe omul de rând în grijă). Omul se întâlneşte cu Dumnezeu sau cu un alt om, într-o relaţie de iubire, în această mişcare de urcare coborâre sau anabasis-catabasis, despre care vorbea Părintele Profesor Dumitru Stăniloae, pentru că Iubirea lui 
Dumnezeu este mişcarea lui Dumnezeu spre om, iar „mişcându-se spre Dumnezeu, creatura îşi pune de acord voia cu firea ei, în care Dumnezeu a sădit dorinţa iubirii faţă de El şi puterea de a se mişca spre El. (...) Din iubirea lui Dumnezeu față de făpturi, răsare iubirea lor față de El şi, deci, iubirea lor față de El nu poate fi despărțită de iubirea Lui faţă de ele. De aceea, Sfinții Părinţi nu fac o deosebire între ele. Iubirea făpturilor faţă de Dumnezeu este darul lui Dumnezeu, produs de iubirea lui Dumnezeu faţă de ele, care se întoarce cu rodul iubirii lor spre Dumnezeu. Iubirea prin care ele însele se mişcă spre El, este iubirea prin care Dumnezeu le mişcă spre El. Două persoane care se iubesc nu mai ştiu ce are în această iubire fiecare de la sine şi ce este de la cealaltă" 217 . Această întâlnire creată, într-un punct central, pe care literatura îl numeşte axis mundi sau centru al lumii, poate continua printr-o deplasare pe orizontală, printr-o mişcare de nivelare a raporturilor, deoarece: „creaţia se află pe drumul iubirii, primindu-şi puterea din iubirea treimică şi înaintând spre desăvârşirea ei în unirea cu Sfânta Treime şi cu toți oamenii"218.

Prin urmare, poezia religioasă este o formă concretă de conexiune a omului cu Divinitatea. Numai că, nu toți poeții reuşesc să realizeze această comunicare, astfel încât limbajul divin să fie transpus versuri de mare forţă artistică. Textul religios menține omul în relaţie cu Dumnezeu, în comuniune. $\mathrm{Nu}$ numai poetul, cel care scrie, realizează această comunicare, dar şi cel care citeşte poezia religioasă.

Considerăm că poezia constituie „un exercițiu spiritual”, înțelegând prin acesta „,un mod de a cerceta conștiința, de a medita, de a contempla..., un mod de a pregăti și a predispune sufletul spre mântuirea lui, prin îndepărtarea de la sine a tuturor înclinațiilor neorânduite". Continuăm ideea cu ceea ce susține Ignațiu de Loyola în "Istorisirea pelerinului", că, de fapt, textul poetic este un jurnal al mișcărilor lăuntrice. Putem spune că imaginarul poetic cenian cu tematică religioasă își are seva în destinul dramatic, tensionat care refuză să accepte destinul efemer al omului. Preluând ideea, adăugăm faptul că poezia care dăinuie trebuie să fie învăluită de misticism şi să conțină o undă de filosofie. Pe de altă parte, ,,orice concepție religioasă nu poate fi lipsită de poezie şi de meditare filozofică, iar orice cugetare filosofică trebuie să aibă un suflu de poezie şi o vibrare de credință religioasă" așa cum spunea Traian Ionescu în

217 Părintele Profesor Dumitru Stăniloae, „Sfânta Treime sau La început a fost Iubirea”, Editura IBMBOR, Bucureşti, 2005, pag. 7.

218 Ibidem, pag. 292. 
articolul publicat în Revista „Universul literar” nr.22, număr dedicat lui Panait Cerna.

Deși Panait Cerna se înscrie în tipul de poezie epigonic eminesciană, totuși, nu putem să nu remarcăm că imaginarul său poetic are și o componentă a credinței ca formă concretizată a spiritualității tradiționale. Prin poezia religioasă, Cerna ilustrează o direcție a literaturii, susținută de publicațiile vremii care configurau modelul de existență tradițional. Opera lui este expresia spiritualității româneşti aflată în momente de cumpănă a cunoașterii, când se căutau noi valori culturale.

Lirica religioasă a poetului se înscrie în rândurile poeziei în care subiectul este umanitatea şi nu, individualul. De referință este poezia „Iisus", în care icoana demitizată, Mântuitorul-omul este emblema sacrificiului individual dezrobitor. În poezie, Iisus îşi primeşte osânda cu resemnare şi cu mai multă recunoștință, anticipând cumva ideea că, sacrificiul său se petrece pentru binele întregii omeniri. Această imagine a suferinței, îi aduce laolată pe oamenii care îndură cu umilinţă privațiunile vieții. Am putea identifica aici chiar o similaritate cu viața poetului, „o viață care a fost o tragedie” 219 , așa cum aprecia Ion Trivale în 1913. Aşadar, accentul cade pe latura umană a personalităţii lui lisus în relație cu divinitatea:

„Dar Tu ai sângerat pe negre căi,/ Supt umilinți ce nu le ştie cerul;/ Tu ai gemut când te pătrunse fier,/ De-au tremurat şi ucigaşii tăi."220 scria autorul şi cu toate acestea se întreba emfatic: „Cum au putut să steie laolaltă/ Atâta chin şi-atâta bunătate?" tocmai pentru a sublinia că dragostea față de semeni se transformă în jertfă absolută.

Referitor la acest text, Pompiliu Constantinescu consideră că Panait Cerna a încercat să exprime de fapt, „lupta dintre cugetător și poetul ce vrea săși avânte optimismul pe piscurile mântuitoare ale creației proprii"221. Continuând ideea, în prefața ediției îngrijite de el, Valeriu Râpeanu considera că versurile: „Un om, un om, prin patimile tale!/ Şi, totuşi, cât de sus, lumina mea,/ Te-a inălțat răbdarea sfântă-a ta!/ De mila ta, la glasul tău de jale,/ Să se deştepte morți de mii de vremi/ Şi-adâncul lumii să se înfioare,/ Iar Tu, să ai privirea iertătoare,/ Un om să fii şi tot să nu blestemi!" ar fi, de fapt, esența vieții și destinului poetului însuși.

219 Bălan, D. I., în postfața volumului „Poezii” îl citează pe Trivale, I. din „Convorbiri literare", XLIII, 1909, Ed. Minerva, București, 1981, pag. 178.

${ }^{220}$ Cerna, P. „Floare și genune”, Ed. pentru Literatură, București, 1968, pag. 3.

${ }^{221}$ Constantinescu, P., „Scrieri”, vol. 2, Ed. pentru literatură, București, pag. 273. 
Caracterul omenesc pe care Panait Cerna îl atribuie divinităţii este ceea ce dă originalitate textului. Astfel, acest discurs poetic surprinde potretul unui Iisus înnobilat şi purificat prin durerea răstignirii şi morţii, înălţat prin iubire şi iertare. Asemeni Mântuitorului, Cerna înțelege să se ridice deasupra suferințelor prin nemărginita dragoste. Aşa se explică, de ce poetul consideră iubirea mai presus de legile universului.

"Nici despărțirea, nici mormântul,/ Nici Cel ce ține-n mâni pământull Nu pot să puie-mpotrivirel Acolo unde e iubire...222".

Poezia reflectă concepția lui Cerna, potrivit căreia, dragostea în forma ei pură este, de fapt, forța cu care universul se regenerează, chiar principala armă pentru distrugerea a tot ceea ce este rău. Amplificarea imaginii biblice devine ocazia cea mai potrivită pentru a accentua intens rolul primordial al dragostei omenești. Umanismul poetului se reflectă în icoana unui Chist alegoric, nu a unei Divinităţi abstracte, situate în afară durerii. În acest text, Iisus este om, solidar cu cei umiliți și cei nedreptățiți. Demitizat, Iisus devine exponentul sacrificiului individual izbăvitor. Dacă îl punem în comparație cu Prometeu, simbolul eroului eliberator, constatăm că Iisus își primește supliciul cu resemnare, conștientizând că se sacrifică pentru binele omenirii. Prin acesta se apropie de oamenii care suportă cu smerenie privațiunile cu care se confuntă în viață. Prin suferință stăruitoare, Iisus este ridicat deasupra condiței umane: „Și totuși, cât de sus, Lumina meal Te-a înalțat răbdare sfântă-a Ta!".

Accente optimiste și originale le proclamă și în "Plânsul lui Adam", un alt text care conține o serie de imagini biblice: "De-a fost păcat iubitul, mărire cui l-a scos, / El a făcut păcatul atâta de frumos:/ Un farmec, o beție ce-n veci în tine-o porțil Pe clipa rătăcirii îndur și mii de morți.../ Dar prea e crudă legea ca fiul să spășească:l De-a pururi, fără vină, greșala părintească..."223.

Din textul poeziei se deduce cu ușurință că Cerna își poziționeză eroul pe poziția revoltatului.

În acest text, autorul păstrează scena căderii lui Cain, dar raporturile dintre cei doi protagoniști sunt cu totul diferite, față de ceea ce se mai scrisese până la acel moment. $\mathrm{Nu}$ se poate identifica relația suveran -supus, ci una bazată pe relații familiale, adică tată-fiu. Această schimbare de perspectivă este observată încă de la apariția volumului de poezii în 1910, când în recenzia realizată volumului, Nicolae Iorga nota: „Cain nu e Cain din Biblie, Cain care a ucis, Cain care poartă pe frunte stigmatul osândei și în suflet gândul care mușcă,

${ }^{222}$ Cerna, P., op. cit., pag. 4.

${ }^{223}$ Ibidem., pag. 16. 
făcând să se verse necontenit sângele negru al nelegiuirii, nu e fiul lui Adam, fiul cel dintâi și mai iubit în legăn, e o jertfă, jertfa mâniei unui Cer care ar fi putut să ierte și a cărui menire nu era să semene dihonie între cei de același sânge" 224 .

Alegoria pe care este construită poezia exprimă predilecția autorului pentru dramatizarea ideii poetice. Adam este omul care primește pedeapsa divină de a răscumpăra păcatul originar, cu prețul unei vieți dominate de ură dată moștenire descendeților săi.

Interesant este faptul că, textul este construit sub forma unui monolog dezvoltat pe unitati ritmice de măsura 13/14, monolog pe care Adam îl rostește în fața unui prezențe fictive a Lui Dumnezeu. El îi vorbește divinității, pentru început, despre tinerețea simplă și luminoasă. Vorbește despre fiii care și-au petrecut copilăria în comuniune deplină cu natura și sub îndrumarea părinților. Pentru a evidenția faptul că mânia divină îl poate lovi pe neașteptate pe om, Cerna face o construcție poetică extrem de sensibilă: „Un gând de-aiurea ucigătorul gând/ Și-n Cain, bunul Cain, pătrunse-ntunecat"225. Tocmai această formă a discursului poetic cernian a atras atenția lui Marcello Camelucci care aprecia: „Farmecul acestei poezii este mai mult în dramatismul monologic al lui Adam decât în puritatea și expresivitatea lui formală". Chiar dacă se pot regăsi și imagini nu tocmai reușite, „totul se replăsmuiește și devine strălucitoare ardoarea nicicând stinsă ce arde în pieptul lui Adam" 226.

Despre poezia „Plânsul lui Adam”, cunoscutul autor cernăunțean Ieșan spunea că „,este o poezie interpretabilă din perspectiva liricii de idei și, implicit, a intropatiei. Ea poetizează una din "temele mari" ale omenirii îzvorâtă din miturile biblice" 227 . De formație teoretician și, totodată, bun cu cunoscător al capodoperelor literaturii universale, Cerna a avut libertatea de a adapta tema lui Adam, omului care trăiește în realitatea de la 1900.

Tocmai datorită reinterpretării mitului lui Adam prin originalitatea limbajului, lectorul găsește un orizont imagistic nou. Astfel, textul lui Cerna repune în scenă funcția poetică de limbaj, ceea ce înseamnă că reușește să comunice, în forme imaginate, stări atitudinale dintre cele mai tensionate. De

${ }^{224}$ Iorga, N. „Poezii de P. Cerna” în vol. „Studii literare”, I, București, Ed. Tineretului, 1969, pag. 266.

${ }^{225}$ Cerna, P. „Floare și genune”, Ed. pentru Literatură, București, 1968, pag. 16.

${ }^{226}$ Camelucci, M., „La vita e l'opera din Panaiti Cerna”, Roma, 1935, pag. 78.

${ }^{227}$ Ieșan, A. „P. Cerna, Die Gedankenlyrik( recenzie)” în „Junimea literară, XIII, 1924, nr. 3-4, pag.181. 
aceea, Magda Ursache consideră imperios necesar ca Cerna să fie amplasat „in vecinătatea marilor săi înaintași în ceea ce privește modelarea (Milton), sau inventarea (Byron, Victor Hugo) unor scene mitice.(...) Cerna nu se afirmă cu originalitate absolută, datorită preexistenței modelelor pe care le dezvoltă și le stilizează dintr-o perspectivă proprie și nu prea, cea a simbolisticii relevante, reușind să se salveze de simpla imitație și de epigonism”. ${ }^{228}$

„Trei sburătoare" este un alt text, prin care Panait Cerna preia simbolul Mântuitorului și îl transformă în manieră proprie.Reamintim de la început, acesta este primul text, cronologic vorbind, în care figura lui Iisus apare într-o poezie publicată. ${ }^{229}$ În aceste versuri, El, Trimisul lui Dumnezeu este icoana Golgotei, dar se adresează sufletelor care se îndreaptă spre El: „Din larg apus, trei sburătoarel S-au îndreptat înspre Calvar,/ S-aducă laudă și dar/ Durerii celei roditoare.../ Dar cea dintâi veni-n zadar"230. După cum se observă cu ușurință, simbolul purității este pe cruce, iar trei suflete se înalță pentru a-i aduce ofranda. Extrapolând ideea, prin imaginea păsărilor Cerna reprezintă, de fapt, umanitatea. Continuând analiza mesajului textului, constatăm că fericita veste este încă primită, (aceea de a-L fi găsit pe Domnul, de a urca împreună cu El pe cruce, cu sărăcie alte trei suflete) și că, deja, autorul spune că una dintre acelea sosite a venit în zadar: "Sbura aproape de pământ:/ Își căuta ceva de hrană,/ Și n-avea vreme, nici avânt,/ Să urce până-n vârful sfânt, -/ La omul fără de prihană"231.

Referitor la aceste versuri, Marcello Camilucci în „Viața și opera lui Panait Cerna” îi amintea pe Bobei și Pohonțu că „au indicat personificarea acestui suflet ușor, senzual, doritor doar de a se stinge, pe el însuși, pe omul mediocru care nu știe să-și ridice privirile mai sus de meschina realitate cotidiană"232. Cerna își exprimă metaforic frica de blestemul mediocrității ce creează o stare de instabilitate și simbolizează căutarea neîncetată spre întâlnirea cu absolutul: "Iar când s-a șters de tot din sbor,/ Veni o ciocârlie-n oral Când Crist cerea un ajutor-/ Când duhul morții da fior/ În sufletele tuturora./ Urcă-n văzduh, ca pe o scară,l și smulse cântec din tărie.../ Un imn de blândă primăvarăl $\hat{i} i$

\footnotetext{
228 Ursache, M. de pe http://www.alil.ro/wp-content/uploads/2012/08/MAGDAURSACHE-Panait-Cerna.-Simbolica-relevant\%C4\%83.pdf, consultat la 12 aprilie 2018.

${ }^{229}$ A fost publicată pentru prima dată în revista „Sămănătorul, III, nr. 4, 25 ianuarie 1904

${ }^{230}$ Cerna, P.,op.cit., pag. 24.

${ }^{231}$ Ibidem.

${ }^{232}$ Cerna, C. apud Camelucci, M. „Viața și opera lui Panait Cerna”( fragment), articol publicat în Revista de cultură, literatură și artă „Cetatea culturală”, Seria a III a, an IX, nr.1(73), Cluj-Napoca, ianuarie, 2008, pag. 80.
} 
alină durerea vie:/ Îi ajută lui Crist să moară.../ E pace, ca-n străvechi altare-/ Duiosul, sfântul cântăreț/ Căzu din slăvi amețitoare". Se poate observa că, ciocârlia este simbolul idealistului, a cutezătorului care se avântă, dar apoi se descurajează sau reprezintă spiritul altruismului, al sufletului smerit care se oferă întru totul divinității, iar Dumnezeu acceptă omagiul pentru a muri în pace, lipsit de griji. În versurile expuse mai sus, eul poetic suprinde sufletul cuprins de lumină, dar care nu reușește să obțină chintesența operei spirituale. În antiteză, „Și iată vulturul măreț/ Scăldat în cald apus de soare."care apare drept simbolul conjugării inteligenței cu sentimentalul, care izbândește să susțină lumina ce se propagă de la cruce. Se identifică, astfel, sacrificiul divin, motiv ce reprezintă idealul perfecțiunii umane: omul care a sfidează suferința și, pe care lacrimile și sângerarea îl transformă în nemuritor.

Poezia se încheie cu versurile: „Porni din culmi ca o furtună;/ Dar și-anfrânat avântul jos,/ Tăind cerc larg și maiestos -/ Făcând din sborul său cununăl Deasupra crucii lui Cristos..." care reflectă concepția de influență lui Cerna. De aceea, Marcello Camilluci spune că: „Cerna rămase pentru totdeauna puțin încorsetat, cu tot impulsul religios plin de viață, proiectelor umane, din simpatie intelectuală pentru superomul nietchzeean, pentru lumea ca voință a lui Schopenhauer într-o continuă transformare; acesta e motivul pentru care, din punct de vedere intelectual, se simțea atras de figura lui lisus, care în mod violent ieșea din categoriile umane, cu toate eforturile pentru a-l menține, creând pentru el o nouă căsuță, Perfecțiunea, mereu refuzată oamenilor"233. Așadar, în text, Cristos e Iisus-omul și, dacă ne raportăm la momentul scrierii ultimei strofe, am putea înțelege că, Fiul Lui Dumnezeu, în profunda denaturare suferită în imaterialul său, este o imagine identică cu tradiționala credință tinerească a celui care l-a înfățișat. De altfel, ,,a admis chiar că, îndepărtându-se, s-a menținut mereu figura miraculoasă a unei religii, ca să-i spunem așa, umană, faptul că evoluția conceptului nu a condus consecutiv la o evoluție a reprezentării, înseamnă, și contradicțiile lui o confirmă, că valoarea spirituală primitivă trăiește încă în mare parte în noua reprezentare, cu toate că intelectul o combate"234. Tânărul Cerna a realizat această alegorie dintr-o dorință puternică care se transformă în imagine, în mod natural. Pe măsură trecerii timpului, viziunea poetului se maturizează, se completează și se transformă în "operă organică". Însă, cele două reflectări care compun corpul textului poetic, au avut cu certitudine aceeași geneză, ca și a treia: pornind de la o intuiție

\footnotetext{
233 Ibidem., pag. 81.

234 Ibidem., pag. 81.
} 
fantastică au obținut apoi „,acea valoare de simbol care, așa cum a demonstrat Cerna, are toată marea poezie" 235 , chiar dacă construcția artistică era aleatorie.

Pornind de la ceea ce spunea Aristotel că "poetul e un imitator, asemenea pictorului sau oricărui alt artist, care dă formă imaginilor" puntem considera că, poetul religios este un imago Dei, pentru că, prin căutarea permanentă dincolo de lumea profanului, a lui Dumnezeu, poetul ajunge să-L imite. Fără a-l înscrie pe Panait Cerna ca un poet religios de mare rang, se poate observa că poezia sa religioasă este o mişcare spre Dumnezeu, orientată mai mult pe verticală: de la om spre Dumnezeu, de la Dumnezeu spre om, apoi de la om la alt om, de la poet către cititori. Așadar, poezia cerniană este construită pe o mişcare concentrică, nu lineară, ea urmărind să transmită un mesaj profund printr-o diversitate de imagini artistice, de alegorii, de teme şi motive recurente. Textele sunt dinamice. Datorită acestei mişcări ale textului, cititorul poate pătrunde în fluxul gândirii autorului şi poate empatiza cu percepțiile, judecățile şi experiențele acestuia. ${ }^{236}$

Poetica religioasă a lui Panait Cerna stă sub semnul intertextualităţii şi transtextualităţii. Sunt necesare trei momente ale producerii şi ale receptării textului, conform teoreticianului H. R. Jauss, pentru ca textul să fie deplin înțeles: poiesis (actul de scriere a textului), aisthesis (momentul receptării) şi katharsis (efectul de purificare produs de text). De aceea, se impune o lectură de suprafață, dar și de adâncime pentru a înțelege pe deplin mesajul pe care poetul îl transmite. Am putut demonstra acest proces prin textele cerniene mai sus analizate, deși textele de inspirație religioasă sunt mult mai multe. Raportândune la perioadele creației cerniene, am putea spune că 1905-1913 reprezintă perioada în care poezia lui Cerna capătă accente religioase. Explicația pe care o putem aduce în suținerea acestei idei, ține de biografic: boala de care Panait Cerna suferise încă din copilărie se accentuează, astfel că poezia sa devine o poezie premonitorie. „Preocuparea pentru dobândirea celor trei calități christice: de trimis, de martor și de mărtirisitor face din Panait Cerna un poet atins de lumină (a)sfințită. Iubirea cuprinsă în învățătura biblică, se arată întreagă, în

\footnotetext{
235 Ibidem., pag. 82.

236 Textul are semnificaţie doar în măsura în care această dialectică dintre autor şi cititor este un proces cu caracter productiv.”, Părintele Profesor John Breck, „Sfânta Scriptură în Tradiţia Bisericii", Ed. Patmos, Cluj-Napoca, 2003, pag. 131 A.
} 
toată splendida ei înțelepciune și este prezentă în temele abordate în poeziile sale: iubirea față de celălalt" 237 .

Așadar, imaginarul poetic de inspirație religioasă oglindește transindividualul, subiectul fiind umanitatea, astfel că, lirica sa se dezvăluie dintr-o perspectivă consolatoare și, totodată, mântuitoare a ceea ce va urma. De aceea, prin aceste texte, Panait Cerna se poate înscrie pe linia poeților religioși din perioada interbelică.

\section{BIBLIOGRAFIE:}

Antofi, Simona, General Dictionary of Romanian Literature - Obverse and Reverse Critical Reception, în Oana Cenac (coord., edit.), volumul MANIFESTARI ALE CREATIVITATII LIMBAJULUI UMAN, 2014, p. 13-19, ISBN:978-606-17-0623-5, Accession Number WOS:000378446400001 https://apps.webofknowledge.com/full record.do?product=WOSEsearch mode=General SearchEqid=2ESID=N1izysiav2ciPKZmp8PEpage $=1 \mathcal{E}$ doc $=3$

Bălan, D. I., în postfața volumului „Poezii” în citează pe Trivale, I. din "Convorbiri literare”, XLIII, 1909, Ed. Minerva, București, 1981;

Cenac Oana, Discurs ideologic în "Ateneu" 1965, Actele conferinței internaţionale Lexic comun / Lexic specializat. Democratizarea cunoașterii" sau migrația lexicului specializat spre lexicul comun, ediția a X-a, Universitatea „Dunărea de Jos” din Galați, Facultatea de Litere, Centrul de Cercetare Comunicare interculturală și literatură, 19 - 20 mai 2017, publicată în Analele Universității „Dunărea de Jos” din Galați, Fascicula XXIV Lexic comun / lexic specializat, revistă indexată in bazele de date internaționale EBSCO: https://www.ebscohost.com/titleLists/cmscoverage.pdf, MLA (Modern Language Association, New York, www.mla.org) MLA International Bibliography \& Directory of Periodicals, CEEOL și Fabula. La recherche en littérature (www.fabula.org), anul X, nr. 2(18) /2017, Editura Casa Cărții de Ştiință, Cluj-Napoca, 2017, ISSN 1844-9476, p. 31-48.

Cenac Oana, General aspects of current political terminology, în Lexic politic - discurs politic, 2014, p.124-130, ISBN:978-606-17-0633-4, WOS: 000378358200007.

Cerna, C. apud Camelucci, M., „Viața și opera lui Panait Cerna” (fragment), articol publicat în Revista de cultură, literatură și artă „Cetatea culturală”, Seria a III a, an IX, nr.1(73), Cluj-Napoca, ianuarie, 2008;

${ }^{237}$ Cerna, D. "Panait Cerna, scepticul luminos", Ed. Casa Cărții de Stiință, Cluj-Napoca, 2009, pag. 406. 
Cerna, D., „Panait Cerna, scepticul luminos”, Ed. Casa Cărții de Stiință, ClujNapoca, 2009;

Cerna, P., „Floare și genune”, Ed. pentru Literatură, București, 1968;

Constantinescu, P., „Scrieri”, vol. 2, Ed. pentru literatură, București;

Ieșan, A., „P. Cerna, Die Gedankenlyrik (recenzie)” în „Junimea literară, XIII, 1924, nr. 3-4;

Ifrim, Nicoleta, Education and Interculturality in Approaching Post-totalitarian Identity Discourse: Interactive Views on Re-reading the Romanian Cultural Identity, Procedia-Social and Behavioral Journal (ISSN: 1877-0428) (ISSN: 1877-0509), vol. 93 / 2013, pp.18-22;

Iorga, N., „Poezii de P. Cerna” în vol. „Studii literare”, I, București, Ed. Tineretului, 1969, pag.266;

Părintele Profesor Dumitru Stăniloae, „Sfânta Treime sau La început a fost Iubirea", Ed. IBMBOR, Bucureşti, 2005;

Părintele Profesor John Breck, „Sfânta Scriptură în Tradiția Bisericii”, Ed. Patmos, Cluj-Napoca, 2003;

Râpeanu, V., Prefaţă la Volumul „Poezii”, Bucureşti, Editura pentru literatură, 1963;

Ursache, M., de pe http://www.alil.ro/wp-content/uploads/2012/08/MAGDAURSACHE-Panait-Cerna.-Simbolica-relevant\%C4\%83.pdf, consultat la 12 aprilie 2018; 